\title{
UPAYA MENINGKATKAN KEMAMPUAN MENGENAL BILANGAN MELALUI TANGGA MANIK-MANIK MONTESSORI DI KELAS A TK ANGGREK KARANGPLOSO
}

\author{
Devi Wahyu Ertanti ${ }^{1}$, Nur Lailatul Maghfiroh² \\ Universitas Islam Malang \\ e-mail: devi.wahyu@unisma.ac.id11, pirotul20@gmail.com²
}

Diterima: 7 April 2021I Direvisi: 15 Mei 2021 I Disetujui: 19 Mei 2021 (C)2021

Pendidikan Guru Raudhatul Atfhal Fakultas Agama Islam Universitas Islam Malang

\begin{abstract}
The purposed of this research was to improved recognized a numbers by the montessori method. For class A at Bina Anaprasa Kindergarten. This study used 25 children without children with special needs. The research method was classroom action research. Data collection techniques used observation, interviews and documentation. Analysis techniques were qualitative for analyzed cycles and qualitative for compared results. Data sources were the activitied of the teacher and the results of the development of recognized a numbers. The results of the study were the ability to recognized numbers increases. $24 \%$ in the first cycle and $76 \%$ in the second cycle. Learn was did by played. In accordance with the child's development and integrated thematic uses for other developments.
\end{abstract}

Kata Kunci: number, montessori method, earlychilhood

\section{A. Pendahuluan}

Usia 4-6 tahun merupakan masa peka yang akan terjadi secara spontan dan tidak dapat terulang kembali, masa ini adalah masa-masa penting bagi anak untuk mengembangkan seluruh aspek perkembangannya secara seimbang, karena menurut pendapat Kartini (2013), bahwa usia TK adalah usia golden age karena seluruh aspek perkembangannya telah siap untuk dikembangkan, maka dari itu menstimulus seluruh aspek perkembangan pada anak TK dirasa tepat. Hal ini sejalan dengan pendapat Montessori (2013), bahwa perkembangan anak tahap awal dibagi menjadi dua yaitu usia lahir sampai 3 tahun dan usia 3 tahun sampai 6 tahun, sedangkan usia TK adalah usia 4-6 tahun. Montesori menyebut usia TK dengan periode-periode sensitif dan periode otak menyerap, karena anak dapat menerima stimulus dari luar (lingkungan) yang bersifat terarah untuk membangun kemandirian anak. Periode-periode sensitif ini akan berpengaruh pada pendidikan selanjutnya. Periode sensitif adalah masa dimana perkembangan anak telah siap untuk dikembangkan dan harus distimulus secara seimbang. Dari beberapa pendapat di atas, maka penting bagi anak untuk mendapatkan pendidikan agar siap memasuki jenjang berikutnya.

This work is licensed under Creative Commons Attribution Non Commercial 4.0 International License Available online on: http://riset.unisma.ac.id/index.php/fai/index 
Ciri-ciri metode montessori adalah adanya penekanan terhadap aktivitas pengarahan diri pada anak, dan pengamatan klinis dari guru yang berfungsi sebagai fasilitator atau pendamping. Metode ini juga menekankan pentingnya penyesuaian dari lingkungan belajar dengan tingkat perkembangan anak dan peran aktivitas fisik dalam menyerap mata pelajaran secara akademis maupun keterampilan praktik secara langsung. Dalam penelitian ini penggunaan tangga manik-manik sebagai wujud penyesuaian lingkungan belajar dengan tingkat perkembangan anak. penggunaan metode Montessori penerapan tangga manik-manik dapat melatih indra sensorik kemampuan mengenal bilangan pada anak.

Keterampilan berhitung sangat berguna bagi kehidupan sehari-hari, terutama konsep bilangan yang merupakan dasar bagi pengembangan kemampuan matematis,dengan kata lain pengembangan pengetahuan dasar matematika sehingga anak secara mental siap mengikuti pembelajaran matematika lebih lanjut di Sekolah Dasar, seperti mengenalkan konsep bilangan melalui berbagai alat dan kegiatan bermain yang menyenangkan (Rosmiyati \& Wahyuni, 2019).

Pembelajaran tentang bilangan, hingga saat ini masih menjadi sorotan tersendiri di mata orang tua. Bilangan merupakan simbol matematika seperti apa yang dikemukakan oleh Marhijanto (2008) bahwa bilangan adalah banyaknya benda, jumlah, satuan sistem matematika yang dapat diunitkan dan bersifat abstrak. Pembelajaran mengenal bilangan dengan tujuan menstimulus kognitif anak usia TK banyak yang dilakukan dengan cara pasif. Pembelajaran yang dilakukan guru tidak berpusat pada anak. Anak secara pasif memperoleh pengetahuan sehingga mengurangi nuansa bermain, padahal pembelajaran kognitif dapat distimulus dengan aktif mengingat usia TK adalah usia bermain. Seperti halnya pendapat Price (1989), Guru dapat memberikan wawasan untuk memahamkan konsep matematika contoh: pasar-pasaran akan memudahkan anak untuk belajar penomoran, sedangkan menurut Kamli (1986), kunci dari pemahaman matematika adalah mendorong apa yang mereka lakukan. Dalam perkembangan kognitif anak, tidaklah terlepas dari perkembangan yang lain. Ada beberapa perkembangan yang secara tidak langsung akan berhubungan dan saling berpengaruh salah satunya adalah kemampuan fisik, bagaimana anak-anak belajar tentang bahasa tubuh.

Dari beberapa pendapat tersebut dapat disimpulkan bahwa bilangan adalah angka yang dapat dioperasikan, misalnya bilangan 10 terdiri dari angka 1 dan 0 . Bilangan dapat dioperasikan pada penjumlahan, pengurangan, perkalian, pembagian dll. Pembelajaran mengenal angka erat kaitannya dengan perkembangan kognitif, namun pembelajaran di TK menggunakan tematik terpadu sehingga pada saat anak mengenal bilangan, mereka tidak hanya belajar tentang bilangan saja melainkan aspek perkembangan lain akan ikut terstimulus.

Pembelajaran di TK juga harus dilakukan dengan bermain karena menurut Menurut Anderson (2010), ada banyak sekali manfaat bermain, anak-anak dapat belajar untuk berpikir, mengingat serta memecahkan masalah, karena dengan bermain beberapa perkembangan anak terstimulus karena beberapa pembelajaran dapat tercakup dalam bermain. Diperkuat oleh pendapat Zaporozhets (dalam Leong 
dan Elena, 2012) yang menyatakan bahwa, pendidikan prasekolah adalah cara untuk mengoptimalkan potensi peserta didik secara seimbang dan tidak bisa ditempuh dengan kelas akselerograf yang bertujuan mempersingkat masa kanakkanak. Itulah uniknya prasekolah yang di dalamnya terdapat gambaran bagaimana anak bermain dan berinteraksi dengan teman sebaya serta orang dewasa.

Pembelajaran mengenal bilangan melalui tangga manik-manik adalah hal dasar yang harus dipelajari anak sebelum mengenal bilangan, karena hal-hal dasar adalah hal penentu ke pembelajaran tingkat selanjutnya. Hal ini dikuatkan oleh pendapat Montessori (2013: 78), bahwa usia TK adalah periode-periode sensitif dan periode otak menyerap, karena anak dapat menerima stimulus dari luar (lingkungan) yang bersifat terarah untuk membangun kemandirian anak. Periodeperiode sensitif ini akan berpengaruh pada pendidikan selanjutnya. Periode sensitif adalah masa dimana perkembangan anak telah siap untuk dikembangkan dan harus distimulus secara seimbang. Tangga manik-manik adalah permainan mengenal konsep banyak benda mulai dari 1 hingga 10 dengan warna berbeda. Tidak hanya itu, dengan tangga manik-manik yang diciptakan oleh dokter Montessori juga mempelajari tentang konsep tinggi rendah serta urutan bilangan yang menjadi pondasi sebelum anak mengenal simbol-simbol angka. Media pemelajaran ini juga dikembangkan oleh Beaty (2010) yang mengembangkan tentang stimulus perkembangan kognitif pada anak menjadi beberapa antara lain: (a) bangun ruang, (b) warna, (c) ukuran, (d) urutan pola, (d) bilangan. Dengan begitu metode pengembangan pembelajaran mengenal bilangan melalui tangga manik-manik dapat di lakukan di TK karena sesuai dengan perkembangan anak dan melalui bermain.

Masalah yang timbul di pendidikan TK adalah anggapan masyarakat bahwa sekolah TK adalah sekolah membaca, menulis dan berhitung, sehingga Guru lebih menitik beratkan pembelajaran pada membaca, menulis dan berhitung. Berhitung adalah hal yang erat dengan matematika, hal ini diungkapkan oleh Gordon (2011) yang menyatakan bahwa matematika erat hubungannya dengan kognitif anak yang berarti belajar kecakapan mengingat dan berpikir abstrak. Belajar matematika berarti belajar angka. Mengenal angka adalah mengenal banyak benda yang kemudian disimbolkan dengan bilangan, sehingga arah berpikir anak dituntun ke arah yang abstrak. Menurut Sulyandari (2016) pembelajaran mengenal bilangan seharusnya melalui tahap mengenal banyak benda terlebih dahulu kemudian mengenalkan bilangan, namun menurut observasi awal di TK Bina Anaprasa, banyak guru yang langsung mengenalkan bilangan pada anak, sehinga anak mengalami kesulitan dalam mengenal bilangan terlebih jika dioperasikam misalnya $1+1=\ldots$. Sebagai indikator rendahnya kemampuan anak di PAUD tersebut, dapat dilihat bahwa dari 27 siswa kelompok Ayang sudah mengenal bilangan hanya 8 siswa (30\%), dan sisanya sebanyak 19 siswa (70\%) belum mengenal angka.

Pada pembelajaran manik-manik tangga ini anak diminta untuk mengurutkan dari manik-manik yang paling pendek ke arah yang paling panjang. Paling pendek diisi oleh satu manik-manik dan yang paling panjang diisi oleh 
sepuluh manik-manik. Satu deret manik-manik memiliki warna yang berbeda, sehingga jika anak belum memiliki kemampuan untuk menghitung banyak manikmanik, maka ia akan mengurutkan sesuai ukuran dibantu dengan mengenal warna.

Berdasarkan paparan pada latar belakang tersebut yang telah diuraikan, maka judul penelitian ini adalah "Upaya Meningkatkan Kemampuan Mengenal Bilangan Melalui Tangga Manik-manik Montessori di Kelas A TK Anggrek Karangploso” Hal ini dimaksudkan untuk meningkatkan pemahaman konsep bilangan sebelum anak dapat mengoperasikan bilangan.

\section{B. Metode}

Penelitian yang digunakan adalah Penelitian Tindakan Kelas (PTK), yang merupakan penelitian tindakan oleh guru yang dilakukan di dalam kelas dengan tujuan untuk memperbaiki kinerja guru sehingga hasil belajar anak mengalami peningkatan (Wardani, 2003). Penelitian Tindakan Kelas (PTK) yang dimaksud dalam penelitian ini adalah proses belajar mengajar di kelompok A TK Anggrek Karangploso dengan menggunakan media tangga manik-mank montessori untuk meningkatkan kemampuan mengenal bilangan.

Subjek penelitian adalah anak kelas A1 yang terdiri dari 25 anak laki-laki dan perempuan dan tanpa anak berkebutuhan khusus. Variable yang digunakan adalah melihat pada proses pembelajaran yang dilakukan anak-anak TK Anggrek Karangploso, melihat cara guru dalam merencanakan proses pembelajaran dan pelaksaannya upaya peningkatan wawasan guru dan pengembangan materi di kelas, melihat media yang digunakan oleh guru dalam proses pembelajaran. Penelitian ini dikelompokkan menjadi 2 siklus yang tiap siklus terdapat beberapa tahap atau langkah. Adapun tahap-tahap atau langkah tersebut yaitu: (1) tahap perencanaan, (2) tahap pelaksanaan tindakan, (3) tahap pengamatan dan interpretasi, (4) tahap analisis dan refleksi.

Siklus I terdiri dari perencanaan, pada tahap ini dibuat RKH, sehingga peneliti mudah melaksanakan tindakan atau pembelajaran dengan harapan penggunaan media tangga manik-manik montessori meningkatkan kemampuan pada anak, terutama dalam perkembangan kognitif. Adapun tahap perencanaan tindakan sebagai berikut: (1) peneliti melakukan observasi awal untuk mengetahui hal-hal apa saja yang akan disampaikan kepada anak-anak menyesuaikan dengan model pembelajaran dan tema yang ada di lembaga, (2) membuat $\mathrm{RKH}$, (3) membuat skenario pembelajaran, (4) menyusun lembar observasi untuk mencatat situasi belajar mengajar selama pembelajaran berlangsung, (5) membuat instrumen penelitian, (6) menyusun evaluasi pembelajaran, (7) merencanakan analisa hasil tes.

Implementasi tindakan adalah melaksanakan kegiatan belajar mengajar di kelas sesuai dengan rencana yang telah dituangkan dalam RKH. Adapun rencana implementasi tindakan adalah sebagai berikut: (1) Guru menciptakan kondisi belajar yang lebih baik, (2) Guru menyampaikan dan menyajikan media yang akan digunakan, (3) Guru menyiapkan alat dan bahan yang diperlukan.Pengamatan 
dilakukan selama kegiatan berlangsung. Hal-hal yang diamati adalah (1) aktivitas performa guru di kelas dalam menyampaikan materi, (2) aktivitas anak siswa di kelas, (3) keberhasilan penggunaan media. Evaluasi hasil belajar dilakukan pada tiap akhir siklus. Kegiatan yang dilakukan pada tahap ini adalah: (1) melihat kekurangan dalam proses belajar mengajar (2) mengadakan perbaikan untuk melaksanakan siklus berikutnya.

Refleksi dilakukan pada akhir siklus. Pada tahap ini, peneliti mengkaji pelaksanaan dan hasil yang diproleh dalam pemberian tindakan kelas pada suatu siklus, dan hasil dari refleksi ini digunakan sebagai dasar untuk memperbaiki serta menyempurnakan perencanaan dan pelaksanaan tindakan pada siklus selanjutnya. Siklus II pelaksanaan siklus kedua ini memiliki urutan yang sama dengan siklus satu. Apabila siklus pertama belum ada peningkatan, maka akan dilanjutkan pada siklus kedua ataupun siklus selanjutnya.

\section{Gambar 1. Siklus Penelitian Tindakan Kelas Model John Elliot}

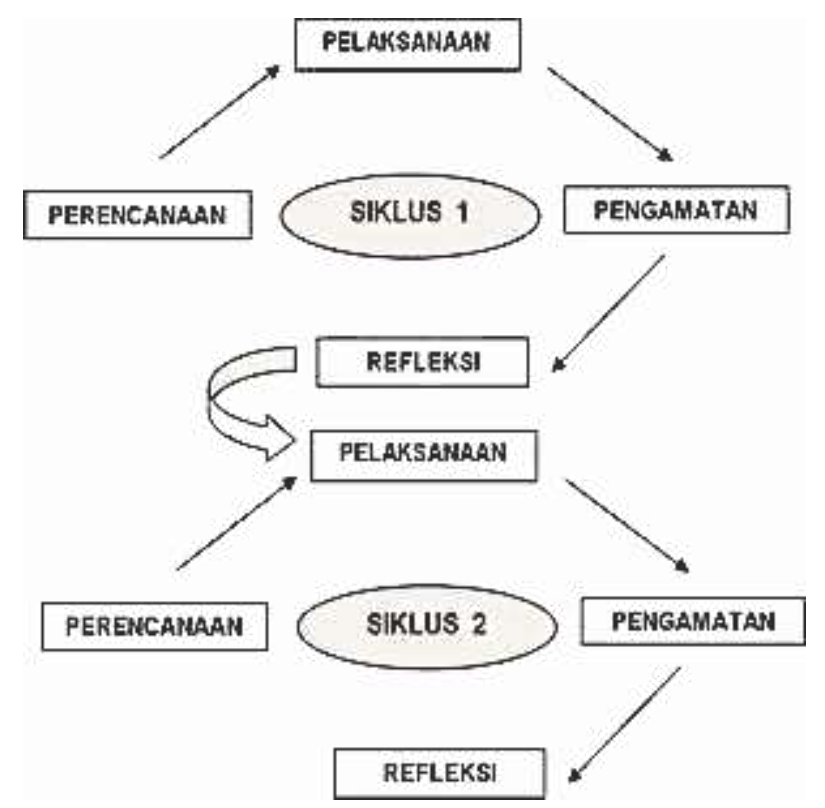

Sumber: (Hopkins, 2014)

Teknik pengumpulan data mengguankan observasi, wawancara dan dokumentasi. Data yang diambil ketika observasi adalah implementasi guru terhadap RKH, sikap guru dalam membantu pemahaman anak-anak tentang bilangan, proses aktivitas anak-anak saat menggunakan media tangga manik-manik, dan tingkat pemahaman anak-anak tentang bilangan. Wawancara dilakukan menggunakan pedoman wawancara yang telah disiapkan sebelumnya, meliputi: guru pada siswa tentang kepahaman mereka menggunakan media, interaksi saat pembelajaran dan mengetahui tingkat kepahaman bilangan melalui media tangga manik-manik. Dokumentasi dilakukan pada saat proses pembelajaran berlangsung 
menggunakan teknik perekaman dan foto, agar memudahkan peneliti menganalisis proses pembelajaran.

Analisis data menggunakan tehnik deskriftif kompratif digunakan untuk data kuantitatif, yaitu dengan membandingkan hasil antar siklus. Analisis ini juga digunakan untuk menghitung nilai atau skor yang diproleh siswa yaitu besarnya peningkatan kemampuan dalam mengenal bilangan. Hasil komparasi tersebut digunakan untuk mengetahui indikator keberhasilan dan kegagalan dalam setiap siklus. Tehnik analisis kritis berkaitan dengan data kualitatif, yaitu mencakup kegiatan untuk mengungkapkan kelemahan dan kelebihan pada proses pembelajaran untuk memperbaiki ditahap berikutnya.

Kriteria untuk mengukur tingkat pencapaian keberhasilan pembelajaran dalam berhitung dinyatakan telah mencapai tujuan pembelajaran, jika total jumlah anak yang mampu mengenal bilangan mencapai diatas $85 \%$, atau anak yang memiliki kemampuan mulai berkembang sampai berkembang sesuai harapan mencapai $85 \%$.

\section{Hasil dan Pembahasan}

Sebelum melaksanakan Penelitian Tindakan Kelas (PTK), ada beberapa hal yang perlu dilakukan oleh peneliti, diantaranya adalah sebagai berikut: (1) membuat Rencana Kegiatan Harian (RKH), (2) membuat skenario, (3) menyiapkan alat peraga berupa: tangga manik-manik dengan banyaknya manik-manik satu sampai sepuluh butir. Pada pelaksanaan Guru membagikan manik-manik tangga kemudian anakanak mengurutkan manik-manik tangga dari yang terpendek hingga terpanjang. Terpendek adalah satu butir manik-manik dan yang terpanjang adalah sepuluh butir. Guru membantu anak-anak untuk menghitung manik-manik setelah ditata dengan benar. Pada kegiatan penutup Guru melakukan refleksi dengan tanya jawab kegiatan hari ini serta menyanyikan kembali lagu "123", kemudian berdo'a setelah belajar/sebelum pulang.

Tahap pengamatan pada Siklus I, diperoleh temuan (1) Guru tidak mencoba menghitung bersama-sama dengan anak sehingga anak kesulitan dalam menghitung. (2) Kegiatan tidak dimulai dengan apersepsi yang baik, sehingga anak kurang paham apa yang harus dilakukan. (3) Media yang ditunjukkan Guru di papan tulis terlalu kecil, sehingga anak-anak belum mengerti bagaimana cara menggunakan media tersebut. (4) Hanya beberapa anak saja yang paham bagaimana cara menggunakan medianya seperti mengurutkan manik-manik berdasarkan panjang dan pendek. (5) Terdapat beberapa anak lain menyusun tangga manik-manik membentuk bangun geometri dan ada yang asik bermain sendiri. (6) Hasil pengamatan yang sudah dilaksanakan oleh peneliti tentang perkembangan siswa dapat dilihat pada gambar 2 .

\section{Gambar 2. Hasil prestasi siswa siklus 1}




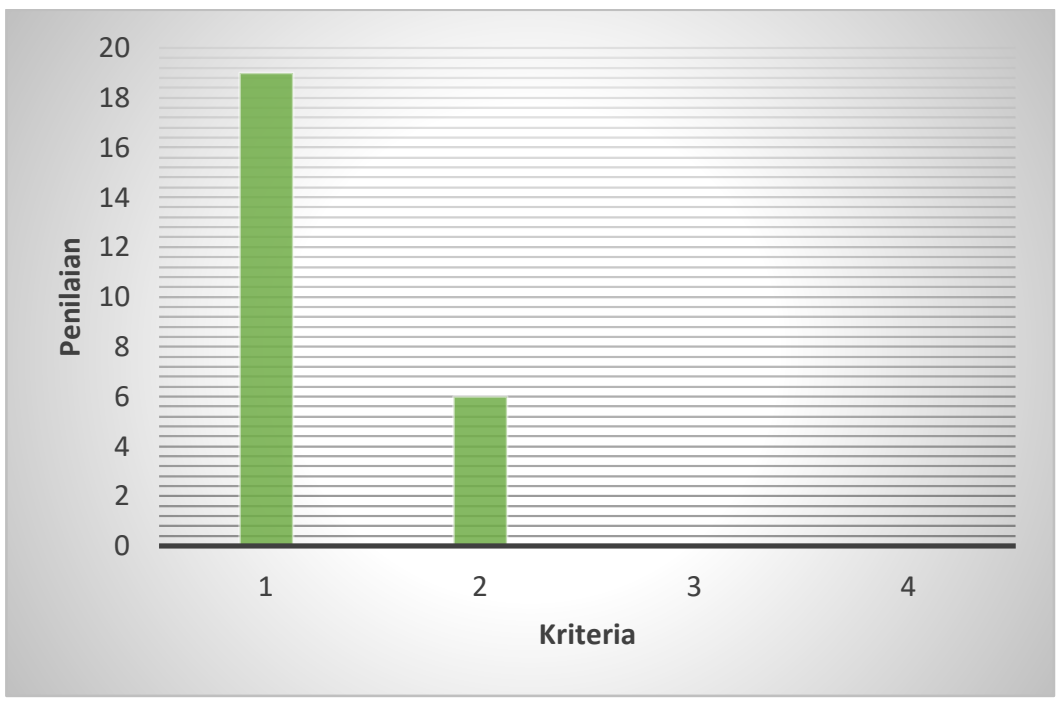

Keterangan:

1 Belum berkembang

2 Mulai berkembang

3 Sudah berkembang

4 Berkembang sesuai harapan

: belum mengerti

:sudah mengerti dengan bantuan guru

:sudah mengerti tanpa bantuan guru

:mengerti dan dapat memandu teman

mengerjakan tugas

Dari data yang tertera pada gambar 2 dapat dijelaskan bahwa anak-anak yang belum berkembang terdapat 19 orang anak (76\%), anak-anak yang sudah mulai berkembang ada 6 anak (24\%). Pembelajaran kali ini belum dikatakan berhasil karna angka pencapaian mulai berkembang hanya $24 \%$ sehingga diperlukan siklus II.

Tahap refleksi dari hasil di atas, terdapat beberapa releksi kegiatan antara lain; (1) guru seharusnya merencanakan apersepsi dengan baik, sehingga anak-anak mengerti apa yang harus dilakukannya. (2) setelah kegiatan bernyanyi, guru memulai percakapan menggunakan media, guru mengenalkan media dan diperjelas dengan gambar. (3) guru memperliharkan cara kerja tangga manik-manik. (4) tahap awal adalah menyusun tangga manik-manik dengan benar, kemudian menghitungnya sama-sama (5) setelah manik-manik tangga tersusun dengan rapi dan benar, barulah bersama-sama guru menghitung banyaknya manik-manik disertai meletakkan kartu bilangan disebelahnya.

Tahap perencanaan pada siklus II, sebelum melaksanakan PTK, ada beberapa hal yang perlu dilakukan oleh peneliti, diantaranya adalah sebagai berikut: (1) membuat Rencana Kegiatan Harian (RKH), (2) membuat skenario, (3) menyiapkan alat peraga berupa: tangga manik-manik dengan banyaknya manik-manik satu ampai sepuluh butir dan kartu bilangan 1-10.

Pada kegiatan belajar Guru membagikan manik-manik tangga pada anak-anak, anak-anak mengurutkan manik-manik tangga dari yang terpendek hingga terpanjang dengan arahan guru dan atau meniru di gambar papan. Setelah semua anak menyusun tangga manik-manik dengan benar, guru membagikan kartu 
bilangan. Guru membantu anak-anak untuk menghitung banyaknya manik-manik setelah ditata dengan benar. Pada kegiatan penutup Guru melakukan refleksi dengan tanya jawab kegiatan hari ini. Mengulang kegiatan hari ini. Guru memberi penguatan kepada anak-anak dengan membahas gambar manik-manik di papan tulis. Guru menata gambar manik-manik sesuai dengan urutannya, menghitung bersama anak-anak dan memberi simbol bilangan di sebelahnya. Guru menyanyikan kembali lagu "123". Berdo'a setelah belajar/sebelum pulang.

Pada hasil observasi diperoleh temuan berupa (1) Dari hasil pengamatan sudah maksimal karena Guru telah melaksanakan kegiatan yang sudah direfleksi, sehingga meminimalisir adanya kekurangan dalam proses belajar mengajar, seperti melakukan apersepsi dengan baik, mengajar pada kegiatan inti lebih terstruktur dan melakukan kegiatan penutup dengan mengulas kembali pelajaran yang telah dilakukan anak-anak. (2) Anak-anak mampu menerima dengan baik perintah guru karna guru menyampaikan perintah tersebut secara terstuktur dan diberi contoh terlebih dahulu di papan tulis, sehingga jika anak kesulitan dalam mengurutkan tangga manik-manik, mereka bisa mencontoh di papan tulis. Anak-anak mengerti konsep banyak benda dengan cara mengurutkan tangga manik-manik dari sedikit hingga banyak, mengerti konsep panjang dan pendek. Anak-anak juga sudah mengenal simbol bilangan setelah menghitung banyaknya maik-manik, karena pada kegiatan awal apersepsi, guru sudah memberi contoh dan menghitungnya bersamasama siswa.

\section{Gambar 3. Hasil prestasi siswa siklus II}

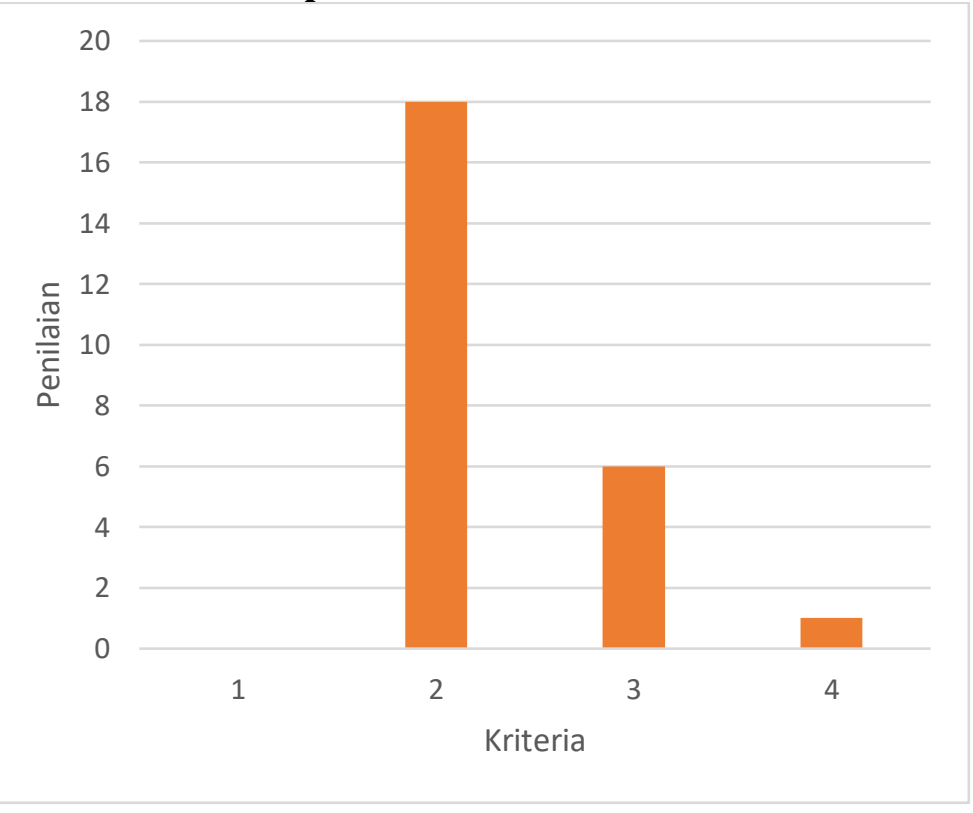

Keterangan: 
1 Belum berkembang

2 Mulai berkembang

3 Sudah berkembang

4 Berkembang sesuai harapan
: belum mengerti

:sudah mengerti dengan bantuan guru

:sudah mengerti tanpa bantuan guru

:mengerti dan dapat memandu teman

mengerjakan tugas

Dari data yang tertera pada gambar 3 dapat dijelaskan bahwa anak-anak yang mulai berkembang terdapat 18 orang anak (72\%), anak-anak yang sudah berkembang ada 6 anak (24\%) dan anak yang berkembang sesuai harapan hanya 1 (4\%). Pembelajaran kali ini sudah dikatakan berhasil karna angka pencapaian di atas $85 \%$ sehingga tidak diperlukannya siklis III.

Hasil observasi yang telah dilakukan oleh peneliti terhadap siklus kedua adalah bertambahnya kualitas dalam proses belajar mengajar dan bertambahnya perkembangan siswa, sehingga penggunaan media tangga manik-manik montessori dalam meningkatkan kemampuan mengenal bilangan yang dilakukan di TK Bina Anaprasa dikatakan berhasil.

Upaya meningkatkan pemahaman anak-anak dalam mengenal bilangan melalui tangga manik-manik montessori tidak hanya memperbaiki kemampuan anak-anak dalam bidang matematika namun juga kemampuan yang lain seperti mengenal konsep panjang pendek, urutan dan warna. Selama proses kegatan berlangsung, aspek perkembangan anak-anak yang lain juga ikut terstimulus yaitu perkembangan seni saat anak mengenal warna, perkembangan bahasa, saat anak melakukan tanya jawab dengan guru, perkembangan nilai-nilai moral agama pada saat anak melakukan berdoa sebelum dan sesudah kegiatan, perkembangan fisik motorik pada saat anak menata manik-manik, hal ini sesuai dengan pembelajaran tematik terpadu yang menjadi prinsip pembelajaran di TK.

Perencanaan belajar juga diperbaiki dalam hal ini yaitu $\mathrm{RKH}$ dan implementasi guru terhadap RKH. RKH disusun dalam nuansa bermain, sehingga anak-anak merasa senang ketika melaksanakan kegiatan. Anak-anak menyusun tangga manik-manik terlebih dahulu agar mengerti banyak benda dan atau mengurutkan berdasarkan panjang pendek, dari panjang pendek anak mngerti konsep banyak benda karena manik-manik dengan roncean satu manik-manik saja adalah terpendek, sedangkan roncean paling banyak adala sepuluh manik-manik menjadi paling panjang. Setelah anak-anak paham konsep banyak benda, Guru meminta anak-anak menghitung banyaknya manik-manik perderet, sehingga anak yang tidak mengerti banyak benda kini bisa mengerti. Aktivitas selanjutnya adalah memberi kartu bilangan di sebelah tangga manik-manik agar anak-anak mengerti banyak benda bserta bilangannya.

Kemampuan adalah perpaduan antara teori dan pengalaman yang diperoleh dalam praktek di lapangan, termasuk peningkatan kemampuan menerapkan teknologi yang tepat dalam rangka peningkatan produktivitas kerja (Tadkirotun, 2012). Menurut Asmani (1996), bahwa kemampuan adalah kapasitas seseorang individu untuk mengerjakan berbagai tugas dalam suatu pekerjaan. Selanjutnya totalitas kemampuan dari seseorang individu pada hakekatnya tersusun dari dua 
perangkat faktor, yakni kemampuan intelektual dan kemampuan fisik. Kemampuan intelektual adalah kemampuan untuk menjalankan kegiatan mental. Kemampuan fisik adalah kemampuan yang diperlukan untuk melakukan tugas-tugas yang menuntut stamina, kecekatan, kekuatan dan bakat-bakat sejenis. Dari beberapa pendapat tersebut, dapat ditarik kesimpulan, bahwa kemampuan adalah pengalaman yang didapat di lapangan berupa kemampuan fisik dan intelektual. Mengenal bilangan melibatkan kemampuan intelektual dan fisik, kemampuan intelektual terlibat pada saat anak berusaha dan belajar dalam memahami banyak benda dan bilangan, sedangkan kemampuan fisik terlibat saat anak mengerjakan tugas yang diberikan oleh guru. Peningkatan kemampuan mengenal bilangan dengan tangga manik-manik montessori dilaksanakan di TK Anggrek Karangploso dengan 25 anak dan tanpa anak ABK. Angka capaian perkembangan awal adalah $24 \%$ di sikulus I dan berkembang menjadi $76 \%$ di siklus II.

\section{Simpulan}

Melalui tangga manik-manik Montessori dapat meningkatkan kemampuan siswa dalam mengenal bilangan. Angka rata-rata yang diperoleh pada kegiatan siklus I mencapai angka 76\% dalam kategori belum berkembang, kemudian pada siklus II mencapai angka rata-rata $72 \%$ dalam kategori mulai berkembang serta pencapaian pembelajaran mencapai rata-rata $85 \%$.

Pengenalan bilangan dilakukan dengan cara bermain yakni menyusun tangga manik-manik sesuai dengan panjang pendek dan atau warnanya, menghitung tangga manik-manik kemudian memberi kartu bilangan di sebelah tangga manik-manik agar anak-anak mengenal banyak benda bersama dengan bilangannya. Proses belajar mengajar menggunakan tangga manik-manik montessori ini tidak hanya mengembangkan perkembangan kognitif saja melainkan dapat mengembangkan aspek lainnya yaitu seni, bahasa, fisik motorik sosial emosional dan nilai-nilai moral agama hal ini sesuai dengan tematik terpadu.

\section{Daftar Rujukan}

Asmani, Jamal Ma'ruf. (2011). Penelitian Tindakan Kelas. Jogjakarta : Laksana. Anderson Jona K. (2010). The Importance of Play in Early Childhood Development. Bozeman: Extension,(Online),(http://store.msuextension.org/publications/ HomeHealthandFamily/MT201003HR.pdf), diakses 3 Februari 2014.

Beaty, J.J. (1996). Skills for Preschool Teachers. New Jersey: Prentice-Hall.

Elliott, J. 1982. Developing Hyphothesis about Classroom from Teachers Practical Construct: an Account of the Work of the Ford Teaching froject. The Action Research Reader. Geelong, Victoria: Deakin University.

Gordon, Ann Miles dan Kathryn Williams Browne. (2011). Beginnings and Beyond. Foundations in Early Childhood Education. America: Delmar Publishers inc. Hopkins, David; Achmad Fawaid. (2011). Panduan guru: penelitian tindakan kelas/ David Hopkins; Alih bahasa, Achmad Fawaid. Yoyakarta:: Pustaka Pelajar 
Hopkins, D. (2014). A teacher's guide to classroom research (Fifth Edit). McGraw-Hill Education (UK).

Kartini, Novalia. (2013). Penerapan Model Pembelajaran Numbered of Head Judul Toghether "Kepala Bernomor" untuk Meningkatkan Kemampuan Kognitif Anak Kelompok B di TK ABA 24 Malang. Jurnal Ilmiah PAUD, 1 (1): halaman 26.

Leong, Deborah J. and Elena Bodrova. (2012). Assessing and Scaffolding Make Believe Play. National Association for the Education of Young Children.

Montesori, Maria. (2013). Metode Montesori. (Gutex, Gerald Lee: Ed). Yogyakarta: Pustaka Pelajar.

Rosmiyati, \& Wahyuni, S. (2019). Meningkatkan Kemampuan Mengenal Konsep Bilangan Anak Usia 4-5 Tahundengan Bermain Kartu Dominodi PAUDNurjannah Pekanbaru. PAUD Lectura: Jurnal Pendidikan Anak Usia Dini, 2(2), 76-85. https://doi.org/https://doi.org/10.31849/paudlectura.v2i02.2517

Sulyandari, Ari Kusuma. (2017). Proses Representasi Simbol Matematika pada Proses Bermain di Anak TK, (Online), (journal.um.ac.id/index.php/jptpp/ article/download/7778/3572), diakses tanggal 25 Agustus 2019

Tadkirotun, Mudfiroh. 2012. Pengembangan Kecerdasan Majemuk.Tangeran: Universitas Terbuka.

Wardani IGAK, dkk. 2008. Penelitian Tindakan Kelas. Jakarta : Universitas Terbuka Rosmiyati, \& Wahyuni, S. (2019). Meningkatkan Kemampuan Mengenal Konsep Bilangan Anak Usia 4-5 Tahundengan Bermain Kartu Dominodi PAUDNurjannah Pekanbaru. PAUD Lectura: Jurnal Pendidikan Anak Usia Dini, 2(2), 76-85. https://doi.org/https://doi.org/10.31849/paudlectura.v2i02.2517 